\title{
Survival and breeding success of the Osprey Pandion haliaetus in Sweden
}

\author{
MATS O. G. ERIKSSON and KJELL WALLIN
}

\section{Summary}

During 1942-1983, the average survival rate of Ospreys in Sweden (as derived from ringing data) was $53 \%$ during the first year, and for older birds it varied between $72 \%$ and $86 \%$ (below the level recorded in North America). The annual survival rate decreased significantly among young birds (1st-3rd years of life) but not among older age classes. A weak relationship between annual survival and rainfall in wintering areas in West Africa may exist for some year-classes.

Breeding success was 2.1 young per successful breeding attempt over the period 19611987 , which is lower than during 1938-1946. The long-term annual growth rate of the population declined from $7 \%$ around 1940 to $5 \%$ around 1990.

A local decline in breeding success occurred during the 1960s and 1970s in areas heavily affected by acid precipitation in south-west Sweden, but this trend halted during the 1980 as liming programmes restored the fish stocks in acidified lakes. There was a significant relationship between lake productivity, measured as concentrations of total phosphorus, and breeding success: at 16 lakes breeding success ranged between 1.6 and 2.3 young per nest per year, and at the most oligotrophic lakes breeding success was close to the minimum required to balance mortality.

The Swedish population of the Osprey is not in acute danger, but the decline in the potential for population growth should be noted.

\section{Introduction}

Scandinavia is a key area for the Osprey Pandion haliaetus population in Europe and North Africa. Out of a total of 5,000-5,500 pairs (Gensbøl 1984), 3,000 pairs breed in Sweden and another 900-1,000 pairs in Finland (Saurola 1976, Widén 1990).

At the beginning of the twentieth century, the Osprey was a rare breeder in Sweden. After total protection in the 1920s, the population increased during the following decades, but since the 1950 s it has remained fairly stable (Österlöf 1973). Counts of the visible autumn migration of raptors at Falsterbo, south-west Sweden, indicate a stable or slightly increasing trend between 1942 and 1988 (concluded from Roos 1978, 1985, 1990).

In Sweden, the Osprey is not endangered or vulnerable but is classified as "care-demanding" in the national Red List; i.e. in order to avoid a future threat, specific requirements must be considered in conservation and land use. At least four factors are latently problematic: pollutants, acidification of fresh waters, disturbance from outdoor recreation, and modern forestry. 
Pollutants, primarily organochlorines and mercury, were recognized as a major threat during the 1960s, but an improvement followed restriction on and prohibition of the use of the most harmful substances from the late $1960 \mathrm{~s}$ onwards. At the beginning of the 1970s, eggshells were on average $15 \%$ thinner than during the 1940s, but around 1980 this thinning was reduced to $7 \%$ (Odsjö and Sondell 1982, 1986). At Lake Vänern, the organochlorine content of eggs decreased significantly during the 1970s (Ahlgren and Eriksson 1984).

Acidification of fresh waters has been identified as a potential threat, and reduced production of young in south-west Sweden during the 1970s was related to the decline of fish populations in acidified lakes (Eriksson et al. 1983).

Disturbance from outdoor recreation, such as fishing, canoeing, sailing and bathing, is problematic to evaluate. There are reports of local declines in breeding success, but also that Ospreys have acclimatized to recreation activities in intensively used areas (see Poole 1981, Hallberg et al. 1983, Odsjö and Sondell 1986). Pairs exposed to heavy disturbance are reported to have shifted from nest-sites on the shore-line to new sites located further from the shore (Odsjö and Sondell 1986).

Modern forestry may contribute to a shortage of nest trees. Normally trees are cut before they are old enough to develop a canopy suitable for nest-building (Persson 1983).

Ospreys start breeding when three years old at the earliest (Poole 1989 and references therein), and are long-lived (maximum longevity 24-25 years: Spitzer 1980, Staav 1989). Thus a decline in reproduction or survival may continue for a long time before the number of adults is affected. In the present paper, we use ringing data to investigate trends in annual survival and production of young, and to assess the potential for annual growth. In addition to a countrywide perspective, we relate differences in reproduction to productivity and acidity in lakes.

The majority of Scandinavian Ospreys winter in West Africa and juvenile birds normally spend their first summer in the tropics (Österlöf 1977). In order to investigate if weather conditions in the winter quarters affected the annual survival, we related the fluctuations in survival rates to rainfall indices for two regions in West Africa.

\section{Material and methods}

\section{Survival}

We used recovery records at the Swedish Ringing Centre in order to estimate the annual survival rate over the period 1940-1980 among birds ringed as nestlings. We used a five-age-class model developed from the three-age-class model by North and Morgan (1979), but excluded the EURING categories <100, 304, 368 and $>499$ due to difficulties in determining the age of death of recovered birds. The model works under the assumption that each cohort had the same recovery rate for all age classes. This assumption was presumably not fulfilled, as the recovery rate may be lower among young, non-breeding birds remaining in the wintering areas than among birds in the breeding areas. This might have 
resulted in an overestimate of the survival rate, especially during the first to third years after hatching.

For calculations of correlations between weather conditions in the winter quarters and annual survival, we used rainfall indices (Marchant et al. 1990), for the wet seasons (May-October), 1962-1988, in two regions in West Africa. Region 1 is delimited by the latitudes $10^{\circ} \mathrm{N}$ and $17^{\circ} \mathrm{N}$, the Atlantic coast and the longitude $5^{\circ} \mathrm{E}$, and includes the south-western part of the Sahel zone. Region 2 is located immediately south of Region 1 and is delimited by the latitude $10^{\circ} \mathrm{N}$, longitude $5^{\circ} \mathrm{E}$ and the Atlantic coast (Figure 3.3 in Marchant et al. 1990). Both regions are used as winter quarters by Ospreys with a breeding origin in northwestern Europe (Österlöf 1977, Staav 1993). We related the estimates of annual survival rates to the rainfall indices during the year of recovery, but also to the mean indices for the year of recovery and the two previous years, because the situation in one particular season, e.g. for foraging, may also be affected by wet or dry conditions during previous years.

\section{Breeding success and annual growth}

We measured breeding success as the mean number of "large nestlings" per successful nest; this is the number of nestlings remaining in the nest when they are advanced enough to be ringed (at least four weeks old), defining a "successful" nest as one that fledges young (Poole 1989). We investigated temporal and geographical trends over a 27 -year period, 1961-1987, using data obtained from the Swedish Ringing Centre.

The material is defective as we have no information on the total number of "active" and "occupied" nests checked by ringers (in the former case, eggs are laid, while in the latter pairs are present regardless of whether eggs are laid: Poole 1989). Thus the number of large nestlings cannot be related to the total number of breeding attempts, including the unsuccessful ones. Furthermore, during the earlier part of the investigation period ringers did not consistently report the number of nestlings not ringed in a nest. This might have resulted in false positive trends in breeding success over time.

For 16 lakes (Figure 1) we related breeding success to lake productivity, as indicated by mean concentrations of total phosphorus in surface water $(0-1.5 \mathrm{~m}$ depth) during the vegetation period (May-October). Generally, a positive relationship exists between productivity and fish biomass, with a dominance of cyprinid fish in the most productive (Swedish) lakes (Persson et al. 1991).

In order to investigate the temporal trends in breeding success in relation to acidification of lakes and the ensuing decline of fish stocks, we compared one area with heavily acidified oligotrophic lakes in south-west Sweden (Area Ac, Figure 2) with one area of oligotrophic lakes less seriously affected (Area Ol, Figure 2). An area where Eriksson et al. (1983) reported a significant decline in breeding success during the 1970 s was delimited as a zone of Area Ac (Area Ac1, Figure 2).

Liming of acidified lakes has turned out to be a successful method of restoring fish stocks, at least on a short-term basis (e.g. Bengtsson et al. 1980, Nyberg 1984, Nyberg et al. 1986, Eriksson and Tengelin 1987), as well as of reducing the levels of mercury in fish (e.g. Björklund et al. 1984, Håkansson et al. 1990), 


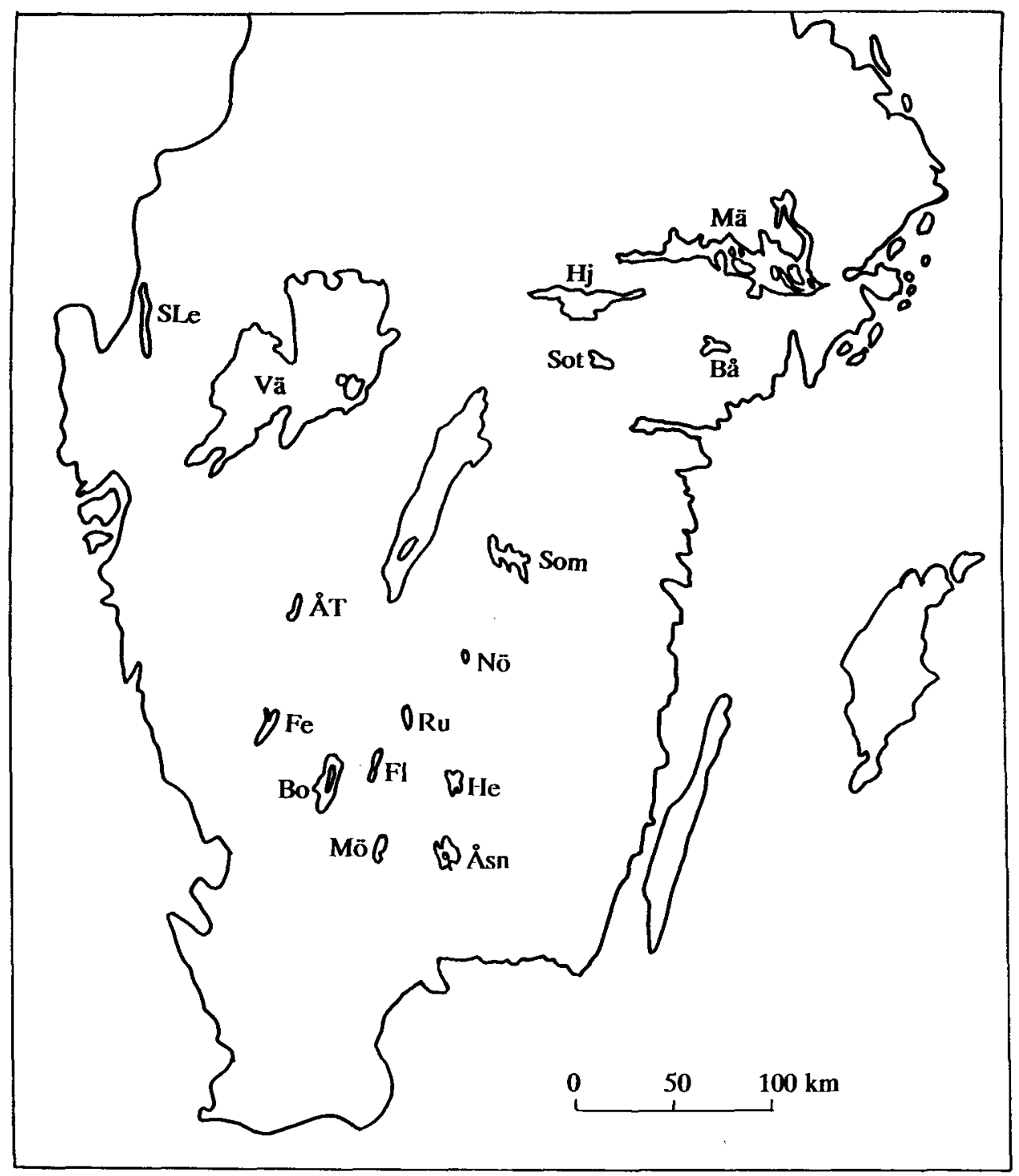

Figure 1. Lakes and lake areas for which breeding success and lake productivity were analysed: Åsn, Lake Åsnen; ÅT, Lake Åsunden/Torpasjön; Bå, Lake Båven; Bo, Lake Bolmen; Fe, Lake Fegen; Fl, Lake Flåren; He, Lake Helgasjön; Hj, Lake Hjälmaren; Mä, Lake Mälaren; Mö, Lake Möckeln; Nö, Lake Nömmen; Ru, Lake Rusken; SLe, Lake Stora Le; Som, Lake Sommen; Sot, Lake Sottern; Vä, Lake Vänern.

and during the 1980 os extensive liming programmes were initiated in Sweden (Brodin 1989). In order to investigate any indication of effects of liming on the production of large nestlings, we compared trends during the periods 19611971 (early phase of lake acidification), 1972-1979 (acidification widespread) and 1980-1987 (extensive liming of acidified lakes). 


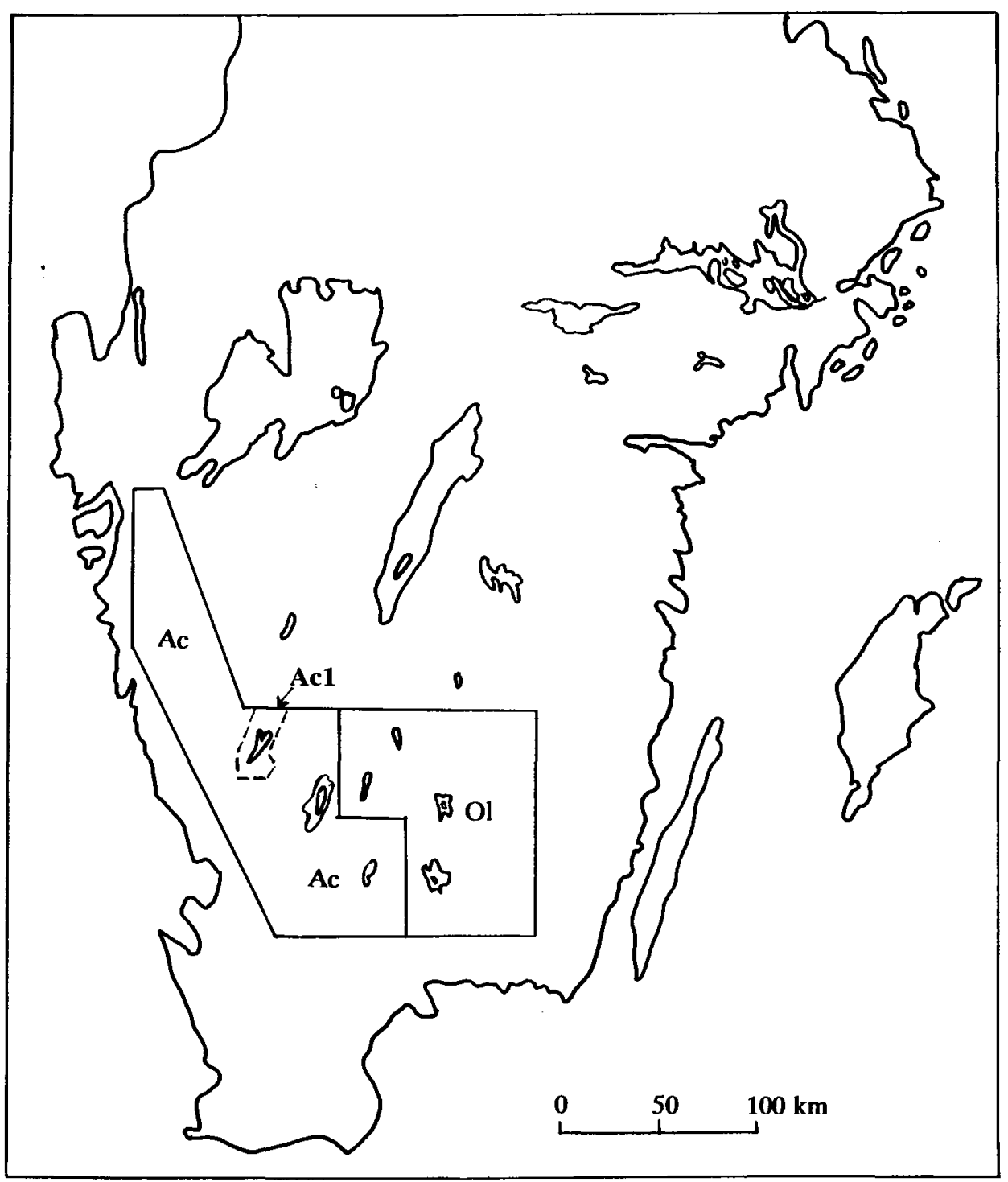

Figure 2. Areas delineated for comparisons of effects of acidification: Ac, dominance of oligotrophic lakes affected by acid precipitation; Ac1, zone where a decline in reproduction was recorded during the 1970 (Eriksson et al. 1983); Ol, dominance of oligotrophic lakes less heavily affected by acidification.

Annual growth rate was estimated from Leslie matrices. For birds during the first, second and third years after hatching, the transient elements of these matrices were estimated from linear regressions between annual survival and time, as significant declines in annual survival over time occurred in these age classes (Figure 3). For older birds we used the mean time-specific survival rate. As we lack information of the age at first breeding in the Swedish population, 


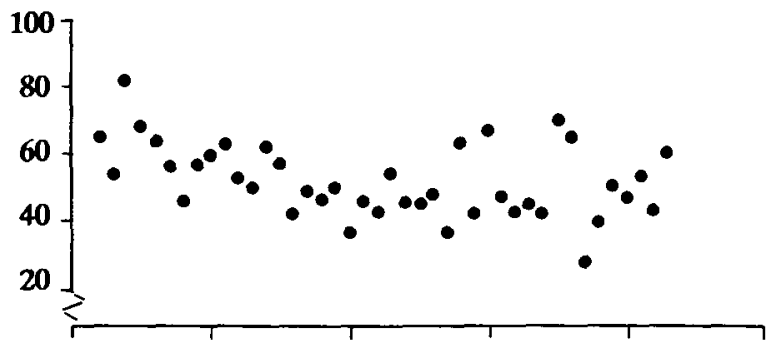

1st year

Spearman $r_{S}=-0.38$

$N=42$ years

$0.005<p<0.01$

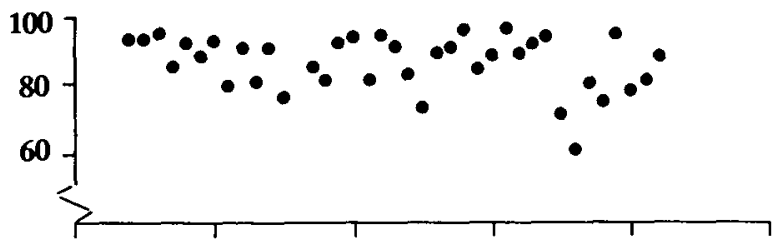

2nd year

Spearman $r_{S}=-0.33$

$N=38$ years

$0.01<p<0.025$

3rd year

Spearman $r_{\mathrm{S}}=\mathbf{- 0 . 3 5}$

$\mathrm{N}=40$ years

$0.01<\mathrm{p}<0.025$

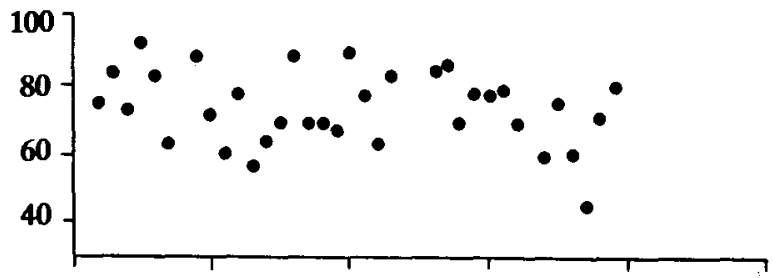

4th year

Spearman $r_{\mathrm{s}}=-0.19$

$N=34$ years

N.S.

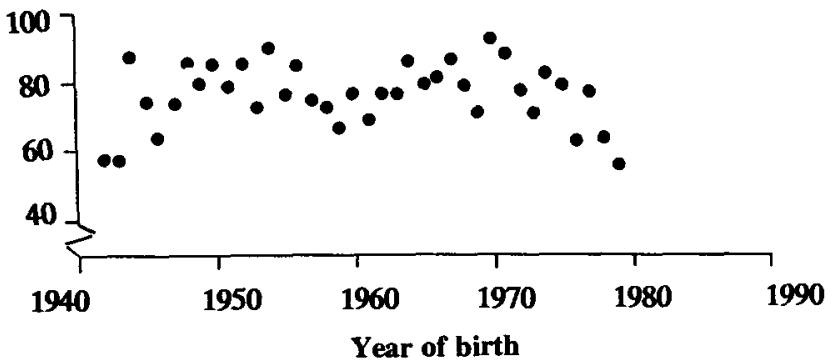

After 4th year

Spearman $r_{s}=-0.03$ $\mathbf{N}=38$ years

N.S.

Figure 3. Temporal trends in yearly survival rates among five age classes. 
we used data from a population on the Atlantic coast of the U.S.A. and assumed that $50 \%$ of the birds nested for the first time when three years old, 30\% when four years old and $20 \%$ when five years old (Spitzer 1980, referenced by Poole 1989). On the basis of the results in the present paper, we assumed the average reproduction to be 1.05 fledged young per female per successful breeding attempt, with no temporal trend and assuming that $75 \%$ of all breeding attempts were successful (based on data by Eriksson et al. 1983). For each year, a Leslie matrix was constructed and the dominant eigenvalue was used as an estimate of the growth rate of the population (e.g. Cullen 1985).

\section{Results and discussion}

\section{Survival}

The number of ringed birds and recoveries in each cohort and age class is given in Table 1. During the period 1942-1983 the average first-year survival was $53\left( \pm \mathrm{SE}_{1.7}\right) \%, 86\left( \pm \mathrm{SE}_{1.3}\right) \%$ during the second year, $72( \pm \mathrm{SE} 2.3) \%$ during the third year, $73\left( \pm \mathrm{SE}_{1.9)} \%\right.$ during the fourth year, and $76\left( \pm \mathrm{SE}_{1.5}\right) \%$ for birds older than four years. For adult birds, the survival rate might have been overestimated as recoveries of birds older than four years were to be expected after the end of the observation period in 1983. Despite this source of error, our estimate of the adult annual survival was below that reported by Poole (1989) for Osprey populations in North America. For young birds, between their first and third years, the annual survival rate declined significantly between the early 1940s and early 1980s (Figure 3).

\section{Annual survival in relation to weather conditions in the winter quarters}

For Region 1, there were no indications of any relationship between rainfall in West Africa and annual survival, but for Region 2 the pattern was less easy to interpret (Table 2). For birds during their first and second year after hatching, the annual survival might have been weakly related to the average rainfall during the present and two previous seasons, and there was a significant correlation between high rainfall and the annual survival of birds during their third year after hatching. Thus, if there are any relationships at all between the rainfall in the winter areas and annual survival, they are weak and exist only for young birds during their first to third years after hatching. The findings of a decline in the annual survival of young, and of weak relationships between survival rates and rainfall indices, are perhaps not mere coincidence, however. With exceptions for single wet years, there has been a general decline in the annual rainfall in West Africa since the 1950s (Marchant et al. 1990).

\section{Breeding success and annual growth}

Odsjö and Sondell (1976) concluded from analyses of ringing data that the average brood size of Ospreys in southern and central Sweden declined significantly from an average of 2.20 large nestlings per successful nest during 19381946 to 2.05 during 1971-1973. We found no general trend in breeding success 
Table 1. Number of ringed nestlings, and number of recoveries included in the survival analyses

\begin{tabular}{|c|c|c|c|c|c|c|}
\hline \multirow[t]{2}{*}{ Year } & \multirow{2}{*}{$\begin{array}{l}\text { Number of } \\
\text { ringed nestlings }\end{array}$} & \multicolumn{5}{|c|}{ Number of recoveries } \\
\hline & & 1st year & 2nd year & 3 rd year & $4^{\text {th }}$ year & $\begin{array}{c}\text { After } 4^{\text {th }} \\
\text { year }\end{array}$ \\
\hline 1942 & 92 & 7 & 0 & 1 & 3 & 5 \\
\hline 1943 & 116 & 6 & 0 & 1 & 1 & 5 \\
\hline 1944 & 146 & 3 & 1 & 2 & 3 & 2 \\
\hline 1945 & 125 & 7 & 1 & 2 & 1 & 6 \\
\hline 1946 & 154 & 9 & 1 & 3 & 2 & 10 \\
\hline 1947 & $\mathbf{1 8 7}$ & 16 & 3 & 1 & 6 & 7 \\
\hline 1948 & 179 & 15 & 1 & 6 & 0 & 4 \\
\hline 1949 & 181 & 13 & 2 & 7 & 1 & 6 \\
\hline 1950 & 256 & 21 & 2 & 7 & 6 & 6 \\
\hline 1951 & 200 & 14 & 5 & 4 & 6 & 9 \\
\hline 1952 & 233 & 21 & 2 & 4 & 4 & 7 \\
\hline 1953 & 201 & 15 & 3 & 5 & 3 & 12 \\
\hline 1954 & 245 & 14 & 2 & 7 & 5 & 4 \\
\hline 1955 & 200 & 13 & 4 & 3 & 3 & 10 \\
\hline 1956 & 254 & 15 & 0 & 3 & 1 & 6 \\
\hline 1957 & 248 & 21 & 3 & 4 & 4 & 11 \\
\hline 1958 & 244 & 16 & 4 & 2 & 5 & 12 \\
\hline 1959 & 197 & 9 & 1 & 4 & 3 & 13 \\
\hline 1960 & 206 & 26 & 1 & 5 & 1 & 7 \\
\hline 1961 & 292 & 30 & 5 & 4 & 4 & 12 \\
\hline 1962 & 294 & 23 & 1 & 8 & 3 & 7 \\
\hline 1963 & 294 & 19 & 2 & 3 & 3 & 9 \\
\hline 1964 & 311 & 27 & 4 & 6 & 0 & 6 \\
\hline 1965 & 251 & 26 & 6 & o & 0 & 11 \\
\hline 1966 & 175 & 10 & 1 & 2 & 1 & 9 \\
\hline 1967 & 158 & 17 & 1 & 2 & 1 & 6 \\
\hline 1968 & 244 & 15 & 1 & 7 & 7 & 10 \\
\hline 1969 & 221 & 17 & 2 & 1 & 2 & 13 \\
\hline 1970 & 229 & 12 & 3 & 3 & 4 & 3 \\
\hline 1971 & 388 & 25 & 1 & 3 & 4 & 7 \\
\hline 1972 & 370 & 25 & 4 & 2 & 4 & 13 \\
\hline 1973 & 336 & 13 & I & 3 & 0 & 15 \\
\hline 1974 & 267 & 18 & 1 & 8 & 2 & 7 \\
\hline 1975 & 236 & 14 & 9 & 11 & 3 & 8 \\
\hline 1976 & 347 & 20 & 14 & 10 & 5 & 13 \\
\hline 1977 & 309 & 23 & 2 & 2 & 3 & 5 \\
\hline 1978 & 464 & 23 & 4 & 2 & 3 & 8 \\
\hline 1979 & 447 & 14 & 1 & 5 & 2 & 8 \\
\hline 1980 & 542 & 15 & 3 & 3 & 0 & - \\
\hline 1981 & 392 & 9 & 2 & 4 & - & - \\
\hline 1982 & 344 & 9 & 1 & 2 & - & - \\
\hline 1983 & 480 & 7 & - & - & - & - \\
\hline
\end{tabular}

in freshwater systems during the period 1961-1987, taking Sweden as a whole (Table 3), and our average of 2.1 large nestlings per successful breeding per year (Table 3) is close to what Odsjö and Sondell (1976) reported for 1971-1973. The brood size among coastal breeders along the Baltic Sea was similar to that among pairs breeding in freshwater systems (Table 3 ). 
Table 2. Spearman rank correlation coefficients, $\mathbf{r}_{\mathrm{s}}$ corrected for ties, for relationships between rainfall indices for the period May-October in West Africa during 1962-1983 and annual survival of Ospreys ringed as nestlings in Sweden

\begin{tabular}{|c|c|c|c|c|c|c|}
\hline \multirow[t]{2}{*}{$\begin{array}{l}\text { Age class, } \\
\text { after } \\
\text { hatching }\end{array}$} & \multicolumn{3}{|c|}{$\begin{array}{l}\text { Correlation between rainfall index for } \\
\text { the year of recovery and survival }\end{array}$} & \multicolumn{3}{|c|}{$\begin{array}{l}\text { Correlation between mean indices of } \\
\text { rainfall for the year of recovery and the } \\
\text { two previous ones, and survival }\end{array}$} \\
\hline & $\begin{array}{l}\text { Region } \\
1 r_{s}\end{array}$ & $\begin{array}{l}\text { Region } \\
2 r_{s}\end{array}$ & $\begin{array}{l}\text { Recovery years } \\
\text { included in the } \\
\text { analyses }\end{array}$ & $\begin{array}{l}\text { Region } \\
\mathbf{1} \mathbf{r}_{\mathrm{s}}\end{array}$ & $\begin{array}{l}\text { Region } \\
2 r_{s}\end{array}$ & $\begin{array}{l}\text { Recovery years } \\
\text { included in the } \\
\text { analyses }\end{array}$ \\
\hline Ist year & -0.04 & 0.13 & $1962-83$ & 0.01 & $0.33^{*}$ & $1964-83$ \\
\hline 2nd year & 0.17 & 0.24 & $1962-83$ & 0.11 & 0.28 & $1964-83$ \\
\hline 3 rd year & -0.02 & $0.52^{* *}$ & $1962-84^{a}$ & -0.01 & 0.27 & $1964-84^{a}$ \\
\hline $4^{\text {th }}$ year & 0.20 & 0.18 & $1962-82^{b}$ & 0.08 & -0.02 & $1964-82^{b}$ \\
\hline Adults & 0.20 & -0.06 & $1962-83$ & 0.14 & 0.13 & $1964-83$ \\
\hline
\end{tabular}

a 1967 excluded (no data on annual survival).

b 1967,1968 and 1976 excluded (no datas on annual survival).

${ }^{*} 0.05<\mathrm{P}<0.10,{ }^{* *} \mathrm{P}<0.01$.

The long-term growth rate of the population declined from $7 \%$ in the early 1940 os to $5 \%$ around 1990. Presumably, this result may be ascribed to decreased annual survival among birds younger than four years, and as indicated above a relationship to a drier climate in the wintering areas may exist. The assessments of annual growth may be somewhat overestimated, however, as we assumed all birds older than five years to breed every year, and because the annual survival of young birds may have been overestimated (see above).

\section{Breeding success in relation to lake productivity}

We found a positive and significant correlation between lake productivity, expressed as the concentration of total phosphorus, and the average production of young (Figure 4). This relationship probably reflects a higher availability of food in productive lakes. Breeding success of Ospreys has repeatedly been found to be linked to food availability (e.g. Poole 1982, 1989, Kushlan and Bass 1983. Eriksson 1986), and the frequency of sibling aggression increases when food is scarce (Poole 1982, McLean and Byrd 1991). The abundance of fish such as percids and cyprinids, which are frequently delivered to Osprey nestlings (e.g. Häkkinen 1978, Nordbakke 1980, 1983, Eriksson 1986), is higher in productive lakes (although the detailed pattern is complicated: e.g. Persson et al. 1991).

Presumably, oligotrophic lakes in Sweden are poor Osprey habitats. Among the lakes included in the productivity analysis, the average number of large nestlings per nest and year ranged between 1.6 and 2.3 (Figure 4). With reference to North America, P. Spitzer (in litt. 1991) concluded that production of young above 2.0 implies good foraging conditions, while values below 1.7 indicate problems with the food supply. Assuming that $75 \%$ of all breeding attempts are successful (from data presented by Eriksson et al. 1983), the range of 1.6-2.3 nestlings per successful nest and year corresponds to a range of 1.2-1.7 large nestlings per active nest. Thus, the most oligotrophic lakes were close to the level of 1.22-1.30 young 
Table 3. Mean number of "large nestlings" per successful breeding attempt per year at freshwater sites in the whole of Sweden and coastal sites along the Baltic Sea

\begin{tabular}{|c|c|c|c|c|}
\hline \multirow[t]{2}{*}{ Year } & \multicolumn{2}{|c|}{ Freshwater sites } & \multicolumn{2}{|c|}{ Coastal sites along the Baltic Sea } \\
\hline & Mean $\pm S E$ & $\mathbf{n}$ & Mean $\pm S E$ & $\mathrm{n}$ \\
\hline 1961 & $2.1 \pm 0.05$ & 197 & $2.3 \pm 0.16$ & 8 \\
\hline 1962 & $2.2 \pm 0.06$ & 124 & $2.6 \pm 0.24$ & 5 \\
\hline 1963 & $2.2 \pm 0.08$ & 116 & $1.9 \pm 0.31$ & 10 \\
\hline 1964 & $2.1 \pm 0.07$ & 127 & $2.4 \pm 0.32$ & 8 \\
\hline 1965 & $2.1 \pm 0.07$ & 109 & $1.7 \pm 0.29$ & 7 \\
\hline 1966 & $2.0 \pm 0.09$ & 80 & $2.3 \pm 0.33$ & 3 \\
\hline 1967 & $2.1 \pm 0.09$ & 73 & $1.3 \pm 0.11$ & 3 \\
\hline 1968 & $2.2 \pm 0.10$ & $7^{8}$ & $1.8 \pm 0.30$ & 6 \\
\hline 1969 & $2.0 \pm 0.08$ & 97 & $2.1 \pm 0.13$ & 7 \\
\hline 1970 & $2.0 \pm 0.08$ & 102 & $1.6 \pm 0.18$ & 8 \\
\hline 1971 & $2.1 \pm 0.05$ & 152 & $1.8 \pm 0.32$ & 8 \\
\hline 1972 & $2.1 \pm 0.06$ & 139 & $2.5 \pm 0.22$ & 6 \\
\hline 1973 & $2.2 \pm 0.07$ & 137 & $2.3 \pm 0.26$ & 12 \\
\hline 1974 & $2.1 \pm 0.07$ & 106 & $2.6 \pm 0.16$ & 10 \\
\hline 1975 & $2.1 \pm 0.08$ & 102 & $2.0 \pm 0.28$ & 12 \\
\hline 1976 & $2.2 \pm 0.06$ & 138 & $2.2 \pm 0.23$ & 13 \\
\hline 1977 & $2.0 \pm 0.06$ & 146 & $2.1 \pm 0.28$ & 10 \\
\hline 1978 & $2.0 \pm 0.05$ & 209 & $2.5 \pm 0.19$ & 12 \\
\hline 1979 & $2.0 \pm 0.07$ & 213 & $2.3 \pm 0.32$ & 8 \\
\hline 1980 & $2.1 \pm 0.05$ & 247 & $2.4 \pm 0.19$ & 15 \\
\hline 1981 & $2.0 \pm 0.05$ & 189 & $2.2 \pm 0.15$ & 9 \\
\hline 1982 & $2.1 \pm 0.06$ & 153 & $2.5 \pm 0.26$ & 11 \\
\hline 1983 & $2.0 \pm 0.05$ & 226 & $1.5 \pm 0.26$ & 8 \\
\hline 1984 & $2.0 \pm 0.06$ & 156 & $2.3 \pm 0.19$ & 17 \\
\hline 1985 & $2.2 \pm 0.07$ & 117 & $1.7 \pm 0.12$ & 16 \\
\hline 1986 & $2.3 \pm 0.06$ & 157 & $2.0 \pm 0.19$ & 11 \\
\hline 1987 & $2.0 \pm 0.07$ & 126 & $1.8 \pm 0.26$ & 4 \\
\hline$N$ (years) & 27 & & 27 & \\
\hline Trend $^{a}$ & -0.18 & & -0.10 & \\
\hline Mean $\pm S E$ & $2.1 \pm 0.02$ & & $2.1 \pm 0.07$ & \\
\hline
\end{tabular}

${ }^{a}$ Spearman $r_{s}$ corrected for ties; no significant relationships.

$n=$ number of nests.

per active nest that Henny and Ogden (1970) estimated to be the minimum to balance the mortality of Osprey populations in the United States.

Breeding success in relation to the exposure of acidifying pollutants

In order to investigate any effects from the decline of fish stocks in acidified lakes, we compared Areas Ac (many acidified likes) and $\mathrm{Ol}$ (oligotrophic lakes less heavily acidified: Figure 2). For Area Ac there was an insignificant negative temporal trend in breeding success, while no trend at all was observed in Area Ol (Table 4). In Area Ac1, where Eriksson et al. (1983) related a significant decline in breeding success between 1973 and 1980 to acidification of lakes and decreased abundance of fish, our data indicate a decrease in breeding success during 1961-1971 (early phase of acidification) as well as during 1972-1979 when acidification became more widespread (Table 4). A levelling-off of the decline in breeding success in 


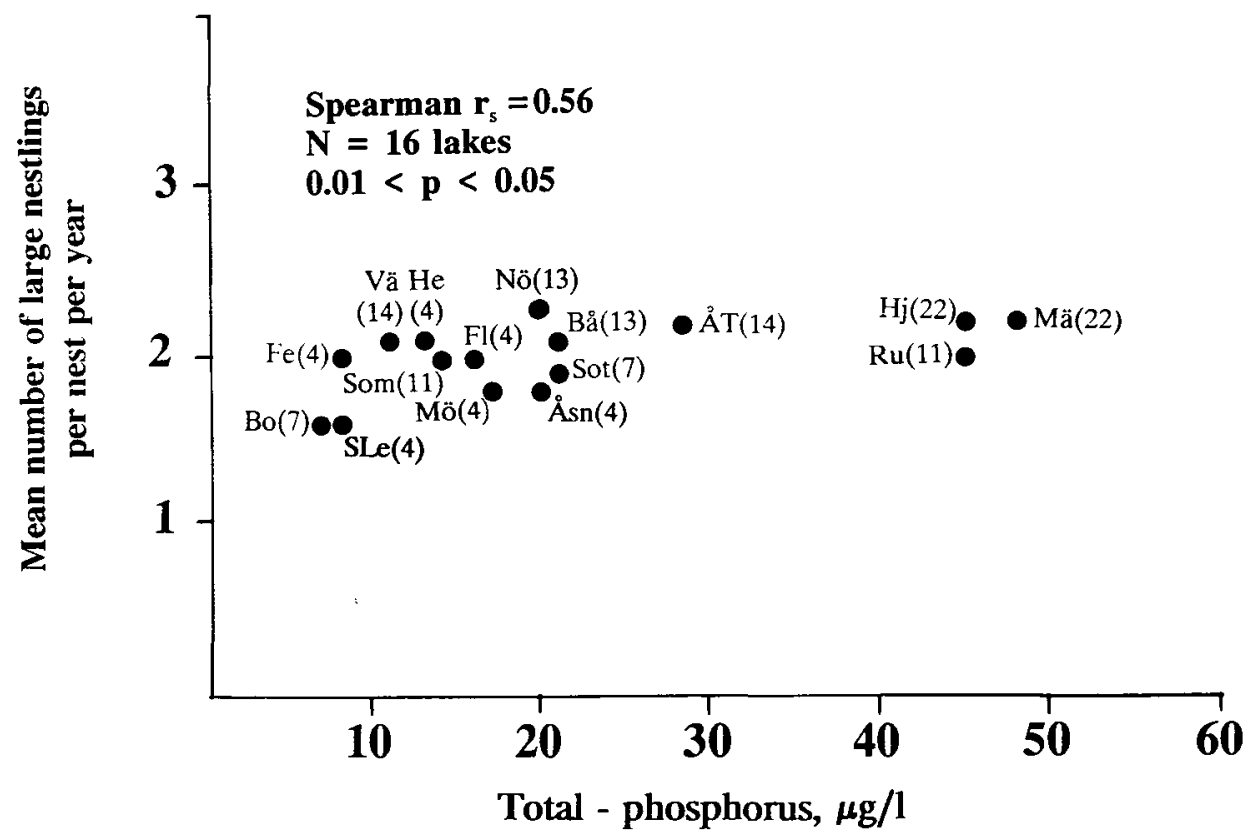

Figure 4. Relationship between breeding success and nutritional status of surface water (0-1.5 $\mathrm{m}$ depth, mean concentrations of total phosphorus per sample per year during May-October; number of years with samples in parentheses). Data on phosphorus concentrations are from Henrikson et al. (1980, 1987), Olsson (1987), Brodin (1988) and the provincial governments in Södermanland, Ostergötland, Kronoberg, Jönköping and Älvsborg. Lake names are abbreviated as in Figure 1.

Areas Ac and Acı during the 1980 s (Table 4) was coincident with the initiation of liming of lakes.

The mean number of large nestlings per nest per year was on the same level in Areas Ol, Ac and Ac1 during the periods 1961-1971 and 1972-1979. During 19801987, it was not significantly different between areas $\mathrm{Ol}$ and $\mathrm{Ac}$, but "almost significantly" lower in Area Acr than in Area Ol (Table 4, Mann-Whitney U test, P = 0.052 , one-tailed). This result lends support to the conclusion of a decreased breeding success in Area Acr.

The decline in breeding success is presumably an effect of reduced availability of prey fish due to acidification, and lowered lake productivity can probably be excluded as an alternative explanation. From recent findings, the existence of any relationship between lowered phosphorus concentrations and acidification processes in fresh waters have to be questioned (e.g. Olsson and Pettersson 1993).

\section{Conclusions}

We found no general temporal trend in reproductive success between 1961 and 1987, but we cannot exclude a general decrease in breeding success in southern and central Sweden since the 1930 and 1940 or or decline in those areas of south- 
Table 4. Mean number of "large nestlings" per successful breeding attempt per year in areas with and without acidified lakes (Ac, Acr and Ol, delimited as in Figure 2).

\begin{tabular}{|c|c|c|c|c|c|c|}
\hline \multirow[t]{2}{*}{ Year } & \multicolumn{2}{|c|}{$\mathrm{Ac}$} & \multicolumn{2}{|l|}{ Acr } & \multicolumn{2}{|l|}{$\mathrm{Ol}$} \\
\hline & Mean $\pm \mathrm{SE}$ & $\mathbf{n}$ & Mean $\pm S E$ & $\mathrm{n}$ & Mean $\pm S E$ & $\mathbf{n}$ \\
\hline 1961 & $2.1 \pm 0.22$ & 8 & $2.3 \pm 0.25$ & 4 & $1.5 \pm 0.19$ & 8 \\
\hline 1962 & $2.4 \pm 0.25$ & 8 & $2.3 \pm 0.39$ & 4 & $2.0 \pm 0.21$ & 5 \\
\hline 1963 & $2.0 \pm 0.00$ & 3 & $2.0 \pm 0.00$ & 2 & $2.3 \pm 0.32$ & 3 \\
\hline 1964 & $1.5 \pm 0.50$ & 2 & - & - & $2.5 \pm 0.29$ & 4 \\
\hline 1965 & $2.0 \pm 1.00$ & 2 & - & - & - & - \\
\hline 1966 & $2.0 \pm 0.41$ & 4 & - & - & $1.8 \pm 0.5^{\circ}$ & 4 \\
\hline 1967 & $2.3 \pm 0.33$ & 3 & - & - & $2.0 \pm 0.37$ & 6 \\
\hline 1968 & $1.8 \pm 0.26$ & 4 & $1.7 \pm 0.33$ & 3 & $2.2 \pm 0.29$ & 10 \\
\hline 1969 & $2.5 \pm 0.29$ & 4 & 2.0 & 1 & $2.3 \pm 0.18$ & 18 \\
\hline $197^{\circ}$ & $1.8 \pm 0.26$ & 4 & $1.7 \pm 0.33$ & 3 & $2.0 \pm 0.14$ & 31 \\
\hline 1971 & $1.7 \pm 0.15$ & 19 & $1.7 \pm 0.22$ & 6 & $1.7 \pm 0.09$ & 42 \\
\hline 1972 & $1.9 \pm 0.27$ & 7 & $2.5 \pm 0.50$ & 2 & $2.2 \pm 0.09$ & 56 \\
\hline 1973 & $2.3 \pm 0.37$ & 7 & $2.4 \pm 0.40$ & 5 & $2.1 \pm 0.13$ & 39 \\
\hline 1974 & $2.2 \pm 0.20$ & 5 & $2.0 \pm 0.00$ & 3 & $2.0 \pm 0.27$ & 8 \\
\hline 1975 & $1.9 \pm 0.36$ & 8 & $1.7 \pm 0.68$ & 3 & $2.1 \pm 0.25$ & 7 \\
\hline 1976 & $2.1 \pm 0.23$ & 8 & $2.3 \pm 0.25$ & 4 & $2.2 \pm 0.12$ & 32 \\
\hline 1977 & $2.0 \pm 0.19$ & 19 & $2.0 \pm 0.25$ & 12 & $2.0 \pm 0.13$ & 26 \\
\hline 1978 & $1.9 \pm 0.15$ & 19 & $1.9 \pm 0.18$ & 14 & $2.2 \pm 0.10$ & 48 \\
\hline 1979 & $1.9 \pm 0.21$ & 15 & $1.9 \pm 0.22$ & 12 & $2.0 \pm 0.10$ & 47 \\
\hline 1980 & $1.9 \pm 0.16$ & 26 & $1.8 \pm 0.26$ & 11 & $2,0 \pm 0.09$ & 74 \\
\hline 1981 & $1.9 \pm 0.13$ & 33 & $1.9 \pm 0.18$ & 20 & $2.1 \pm 0.11$ & $3^{8}$ \\
\hline 1982 & $1.7 \pm 0.22$ & 15 & $1.5 \pm 0.22$ & 10 & $2.1 \pm 0.12$ & 29 \\
\hline 1983 & $2.2 \pm 0.14$ & 30 & $2.1 \pm 0.26$ & 12 & $1.8 \pm 0.09$ & 64 \\
\hline 1984 & $2.0 \pm 0.17$ & 26 & $1.8 \pm 0.24$ & 14 & $1.8 \pm 0.11$ & 32 \\
\hline 1985 & $1.8 \pm 0.15$ & 18 & $1.6 \pm 0.18$ & 8 & $2.4 \pm 0.17$ & 17 \\
\hline 1986 & $2.2 \pm 0.13$ & 27 & $2.1 \pm 0.21$ & 11 & $2.0 \pm 0.12$ & 36 \\
\hline 1987 & $1.8 \pm 0.18$ & 13 & $1.8 \pm 0.17$ & 6 & $2.0 \pm 0.27$ & 11 \\
\hline $\mathrm{N}$ (years) & 27 & & 23 & & 26 & \\
\hline Trend $^{a}$ & -0.20 & & -0.30 & & -0.04 & \\
\hline Mean $\pm S E$ & $2.0 \pm 0.05$ & & $2.0 \pm 0.06$ & & $2.1 \pm 0.04$ & \\
\hline \multicolumn{7}{|l|}{$1961-1971$} \\
\hline$N$ (years) & 11 & & 7 & & 10 & \\
\hline Trend ${ }^{a}$ & -0.30 & & $-0.85^{* *}$ & & -0.01 & \\
\hline Mean $\pm S E$ & $2.0 \pm 0.09$ & & $2.0 \pm 0.10$ & & $2.0 \pm 0.10$ & \\
\hline \multicolumn{7}{|l|}{$1972-1979$} \\
\hline$N$ (years) & 8 & & 8 & & 8 & \\
\hline Trend $^{\mathrm{a}}$ & -0.38 & & $-0.67^{*}$ & & -0.25 & \\
\hline Mean $\pm S E$ & $2.0 \pm 0.06$ & & $2.1 \pm 0.10$ & & $2.1 \pm 0.03$ & \\
\hline \multicolumn{7}{|l|}{$1980-1987$} \\
\hline$N$ (years) & 8 & & 8 & & 8 & \\
\hline Trend $^{a}$ & 0.09 & & 0.05 & & -0.10 & \\
\hline Mean $\pm S E$ & $1.9 \pm 0.07$ & & $1.8 \pm 0.08$ & & $2.0 \pm 0.07$ & \\
\hline
\end{tabular}

a Spearman $\mathbf{r}_{\mathrm{s}}$, corrected for ties.

* $0.025<\mathrm{P}<0.05$, **P $<0.025$.

$\mathrm{n}=$ number of nests. 
west Sweden which were most heavily affected by acidification during the 1960 s and 1970 s.

The annual survival among adult Swedish Ospreys is lower than that reported from North America. Among young birds, less than three years old, the annual survival decreased between the early 1940 s and 1980s, and the existence of a weak effect on survival rates due to weather conditions in the winter areas cannot be excluded. The long-term annual growth rate of the population has decreased from $7 \%$ to $5 \%$ over a 50 -year period between 1940 and 1990 , but it is still above the level which compensates for mortality.

For Scandinavia, optimism (e.g. Odsjö and Sondell 1986, Poole 1989) over the future of the Osprey might be premature. In a short-term perspective the population is not in danger, but the decline in potential population growth must be considered. In Scandinavia, acidification of fresh waters must still be regarded as a potential threat. The recommendation by Eriksson et al. (1983) to give high priority to liming of lakes important for foraging Ospreys still holds, although it is only a short-term solution. In the long run, it is the emission of acidifying pollutants that must be reduced.

\section{Acknowledgements}

This study was supported by the Swedish Environmental Protection Agency. We also thank the staff at the Swedish Ringing Centre, located at the Swedish Museum of Natural History, Stockholm, for valuable assistance during our analysis of the ringing data. Mikael Hake, Bodil Westberg and one referee - N. J. Aebischer - very kindly assisted in the preparation of the manuscript.

\section{References}

Ahlgren, C.-G. and Eriksson, M. O. G. (1984) (The exposure to mercury and organochlorines on Osprey, Pandion haliaetus, in southwest Sweden.) Vår Fågelvärld 43: 299-305 (Swedish, English summary).

Bengtsson, B., Dickson, W. and Nyberg, P. (1980) Liming acid lakes in Sweden. Ambio 9: $34-36$.

Björklund, I., Borg, H. and Johansson, K. (1984) Mercury in Swedish lakes - its regional distribution and causes. Ambio 13: 118-121.

Brodin, Y.-W. (1988) Vänern 1986. Näringsbelastning på Vänern under 1970-och 1980talen. Länsstyrelsen i Skaraborgs län, naturoårdsenheten, meddelande 2/88.

Brodin, Y.-W. (1989) Svensk kalkning: Rapport 1989. Naturvårdsverket Report 3606: 1-20.

Cullen, M. R. (1985) Linear models in biology. Chichester: Ellis Horwood.

Eriksson, M. O. G. (1986) Fish delivery, production of young, and nest density of Osprey (Pandion haliaetus) in southwest Sweden. Can. J. Zool. 64: 1961-1965.

Eriksson, M. O. G., Henrikson, L. and Oscarson, H. G. (1983) (Acid rain - a future danger for the Osprey Pandion haliaetus.) Vår Fågelvärld 42: 293-300 (Swedish, English summary).

Eriksson, M. O. G. and Tengelin, B. (1987) Short-term effects of liming on perch Perca fluviatilis populations in acidified lakes in South-West Sweden. Hydrobiologia 146: 187191.

Gensbøl, B. (1984) Rovfuglene i Europa. Copenhagen: GAD. 
Håkansson, L., Andersson, P., Andersson, T., Bengtsson, A., Grahn, P., Johansson, J.-Å., Jönsson, C.-P., Kvarnäs, H., Lindgren, G. and Nilsson, $\AA$. (1990) (Measures to reduce mercury in lake fish. Final report from the liming-mercury-caesium project.) Naturvardsverket Report 3818: 1-198 (Swedish, English summary).

Häkkinen, I. (1978) Diet of the Osprey Pandion haliaetus in Finland. Ornis Scand. 9: 111116.

Hallberg, L.-D., Hallberg, P.-S. and Sondell, J. (1983) (Changing the location of Osprey nest sites to reduce human disturbance.) Vår Fågelvärld 42: 73-80 (Swedish, English summary).

Henny, C. J. and Ogden, J. C. (1970) Estimated status of Osprey populations in the United States. J. Wildl. Mgmt. 34: 214-217.

Henrikson, L., Larsson, P., Nyman, H. G. and Oscarson, H. G. (1980) Stora Le i Dalsland - en limnologisk undersökning 1979. Länsstyrelsen $i$ Älvsborgs län, naturvårdsenheten 1980: 7 .

Henrikson, L., Nyman, H. G., Larsson, S., Olofsson, J. and Oscarson, H. G. (1987) Åsunden, Yttre Åsunden och Torpasjön - en limnologisk undersökning 1985. Länsstyrelsen $i$ Älvsborgs län, naturvårdsenheten 1987: 13.

Kushlan, J. A. and Bass, O. L. (1983) Decrease in the southern Florida Osprey population, a possible result of food stress. Pp.187-200 in D. Bird, ed. Biology and management of Bald Eagles and Ospreys. Ste-Anne-de-Bellevue, Quebec: Harpell Press.

Marchant, J. H., Hudson, R., Carter, S. P. and Whittington, P. A. (1990) Population trends in British breeding birds. Tring: British Trust for Ornithology.

McLean, P. K. and Byrd, A. B. (1991) Feeding ecology of Chesapeake Bay Ospreys and growth and behaviour of their young. Wilson Bull. 103: 105-111.

Nordbakke, R. (1980) The diet of a population of Ospreys Pandion haliaetus in southeastern Norway. Cinclus (Fauna norv. Ser. C) 3: 1-8.

Nordbakke, R. (1983) On the diet of the Osprey Pandion haliaetus in Norway. Cinclus (Fauna norv. Ser. C) 6: 39-42.

North, P. M. and Morgan, B. J. T. (1979) Modelling heron survival using weather data. Biometrics 35: 667-681.

Nyberg, P. (1984) Effects of liming on fisheries. Phil. Trans. R. Soc. Lond. B 305: 549-560.

Nyberg, P., Appelberg, M. and Degerman, E. (1986) Effects of liming on crayfish and fish in Sweden. Water, Air and Soil Pollution 31: 669-687.

Odsjö, T. and Sondell, J. (1976) Reproductive success in Ospreys Pandion haliaetus in southern and central Sweden. Ornis Scand. 7: 71-84.

Odsjö, T. and Sondell, J. (1982) Eggshell thinning and DDT, PCB and mercury of Osprey (Pandion haliaetus (L.) ) in Sweden and their relations to breeding success. Pp. 65-111 in T. Odsjö, Eggshell thickness and levels of DDT, PCB and mercury in eggs of Osprey (Pandion haliaetus (L.)) and Marsh Harrier (Circus aeruginosus (L.)) in relation to breeding success and population status in Sweden. Ph.D. Thesis, University of Stockholm.

Odsjö, T. and Sondell, J. (1986) (When, and in what way, is the Osprey to be protected?) Vår Fågelvärld 45: 351-358 (Swedish, English summary).

Olsson, H. (1987) Hjälmarens fosfor - och kvävebelastning 1966-1985. Statens naturvairdsverk Report 3309: 1-47.

Olsson, H. and Pettersson, A. (1993) Oligotrophication of acidified lakes - a review of hypotheses. Ambio 22: 312-317.

Österlöf, S. (1973) (The Osprey Pandion haliaetus in Sweden in 1971.) Vår Fågelvärld 32: 100-106 (Swedish, English summary).

Österlöf, S. (1977) Migration, wintering areas, and site tenacity of the European Osprey Pandion $h$. haliaetus (L.). Ornis Scand. 8: 61-78.

Persson, Å. (1983) Rapport från projekt fiskgjuse i Dalarna 1983. Fåglar i Dalarna 16: 127132. 
Persson, L., Deihl, S., Johansson, L., Andersson, G. and Hamrin, S. (1991) Shifts in fish communities along the productivity gradient of temperate lakes - patterns and the importance of size-structured interactions. J. Fish. Biol. 38: 281-293.

Poole, A. (1981) The effects of human disturbance on Osprey reproductive success. Colonial Waterbirds 4: 20-27.

Poole, A. (1982) Brood reduction in temperate and sub-tropical Ospreys. Oecologia 53: 111-119.

Poole. A. (1989) Ospreys: a natural and unnatural history. Cambridge: Cambridge University Press.

Roos, G. (1978) (Counts of migrating birds and environmental monitoring: long-term changes in the volume of autumn migration at Falsterbo 1942-1977.) Anser 17: 133-138 (Swedish, English summary).

Roos, G. (1985) (Visible bird migration at Falsterbo in autumn 1984.) Anser 24: 1-28 (Swedish, English summary).

Roos, G. (1990) Sträckfågelräkning vid Falsterbo. Rapport från verksamheten 1989. Naturvårdsverket Report :3799: 1-15.

Saurola, P. (1976) Finnish raptor censuses. Ornis Fenn. 53: 135-139.

Spitzer, P. R. (1980) Dynamics of a discrete coastal breeding population of Ospreys in the northeastern USA, 1969-1979. Ph.D. Thesis, Cornell University.

Staav, R. (1989) (Longevity of birds ringed in Sweden. Current list 1989.) Vår Fågelvärld 48: 251-275 (Swedish, English summary).

Staav, R. (1993) 1000 tropikăterfynd - vart flyger våra långdistansflyttare? Vår Fågelvärld 52(8): 6-15.

Widén, P. (1990) Aktuella naturvårdsproblem hos våra rovfåglar. Naturvårdsverket Report 3687: 1-73.

MATS O. G. ERIKSSON

Provincial Government in Göteborgs och Bohus län, Department of Environmental Protection, S-403 40 Göteborg, Sweden

KJELL WALLIN

Swedish University of Agricultural Sciences, Department of Animal Ecology, S-9o1 83 Umeå, Sweden 